\title{
Protein Jagged-2
}

National Cancer Institute

\section{Source}

National Cancer Institute. Protein Jagged-2. NCI Thesaurus. Code C84310.

Protein jagged-2 (1238 aa, $133 \mathrm{kDa}$ ) is encoded by the human JAG2 gene. This protein plays a role in cellular differentiation. 